\title{
PACKAGING OF REFRIGERATED STRAWBERRY (Fragaria ananassa) USING PREPARED EDIBLE WHEAT GLUTEN FILMS AND COATINGS
}

\author{
(Received:28.10.2008)
}

\author{
By \\ M. M. Abd El Magied, N. A. Salama, K S. Nagy* and M. R. Ali \\ Department of Food Science and Technology, Faculty of Agriculture, Cairo University, Giza, Egypt \\ *Institute of Technology Research, Agricultural Research Center,Giza, Egypt.
}

\begin{abstract}
Edible films and coatings from wheat gluten were prepared with different concentrations of glycerol (as plasticizer), and at $\mathrm{pH}$ (10). The effect of different wheat gluten films, and coatings on refrigerated strawberry quality, and shelf life was studied. Films with low amounts of glycerol (20\%) had lower water vapor and other properties e.g. tensile strength was recorded the highest value, on the contrary, the water solubility as well as the elongation properties were in lower values at break. The best prepared film properties were for $(25 \%)$ glycerol content. The quality of strawberry fruits packed in wheat gluten film was superior to corresponding fruits packed in perforated polypropylene films for all tested parameters i.e. visible decay, surface color development, weight loss, firmness loss, and sensory characteristics . Different layers were used to prepare different coatings based on wheat gluten: (I) one layer of wheat gluten only. (II) One layer of wheat gluten with beeswax and lipids (stearic, and palmitic acids). (III) bilayer coating of wheat gluten. The bilayer coating had a significant effect on the retention of strawberry firmness, and showed reduction on their weight loss compared with the uncoated fruits. Results showed also that, the gluten coatings were more able to control the decay than those of gluten film (pouch film). Sensory tests after different storage periods at $\left(5^{\circ} \mathrm{C}\right)$ up to 16 days compared with control was done. The coated strawberry maintained their visual quality during storage periods. As a result the taste of gluten coated strawberry was more acceptable at the end of storage compared with the control.
\end{abstract}

Key words: edible coating, glycerol, mechanical properties, quality, shelf life, strawberries, water vapor, wheat gluten films.

\section{INTRODUCTION}

Coating and edible films have long been known to protect perishable food products from deterioration and some types of quality loss. However, over the last decade there has been a rapidly growing interest in the development and use of biobased packaging materials to prolong the shelf-life and improve the quality of fresh, frozen and formulated food products because of the following factors: (a) environmental issues related to disposal of conventional synthetic foodpackaging materials and the need to develop more ecofriendly and biodegradable materials; (b) increasing consumer expectations for a variety of fresh-like foods (e.g. minimally processed fruit and vegetables); (c) the need for food products with extended shelf-life; (d) expanding distribution channels for food commodities; and (e) new opportunities for food products with edible barriers, (Krochta and DeMulder-Johnston 1997). Although many functions of edible films and coatings are identical to those of synthetic films, there are additional requirements pertaining to their use in foods, (Debeaufort, et al., 1998) (a) acceptable sensorial characteristics; (b) appropriate barrier properties (gas, water, oil); (c) good mechanical strength and adhesion; (d) reasonable microbial, biochemical and physicochemical stability; (e) safety for health (free of toxic micro-organisms and hazardous compounds); (f) effective carrier for antioxidant, flavor, color, nutritional or antimicrobial additives; (g) raw materials of low cost; and (h) simple technology for production. Many of the current research efforts on biopackaging of foods aim at one or more of these issues, all relevant to the performance of edible films and coatings. (Diab et al., 2001).

Production and utilization of edible, biodegradable films and coatings prepared from various biological polymers such as polysaccharides, proteins, lipids or combinations of those components have received great interest in recent years. Among other materials, proteins 
have long been used for this biopolymer production, (Kayserilioglu, et al., 2003). Wheat gluten is a biodegradable and crop renewable agropolymer with interesting film-forming properties for the production of biopackaging materials, and its unique among cereal and other plant proteins in its ability to form a cohesive blend with viscoelastic properties once plasticized. In general, gluten-based materials require addition of plasticizer agents, (Mastromatteo, et al., 2008). Glycerol is one of the most popular plasticizer used in filmmaking techniques due its stability and compatibility with hydrophilic biopolymeric chain (Pommet, et al., 2005). These small molecules interact with the polymer chains, thereby lowering forces holding the chains together. Similar to other protein films, wheat gluten films are excellent oxygen and carbon dioxide barriers at low relative humidities with selective permeability to gases (Mujica-Paz and Gontard, 1998).

Recently, there has been an increasing consumers demand for fresh and minimally processed fruits and vegetables due to their freshlike character, convenience, and human health benefits. Fresh fruits and vegetables are characterized by a post-harvest respiration activity, which could be correlated to the deterioration rate of the product during storage (Ahvenainen, et al., 1998). Low storage temperature and/or modified atmosphere packaging (MAP) are commercially used for reducing the respiration rate, delaying senescence and ultimately increasing product shelf-life of packaged fruits and vegetables, (Mujica Paz, and Gontard 1998).

Strawberries are a soft fruit with high respiration and softening rates, making the availability of high quality strawberries challenging. Due to its high metabolism, strawberries must be kept at $4-5^{\circ} \mathrm{C}$, which can extend its high quality for 6 or 7 days. The use of coating or edible film involving strawberries can also be an alternative to improve their shelf- life (Tanada-Palmu, and Grosso, 2005).

The objectives of this study were to investigate the effect of prepared edible wheat gluten films with different amounts of glycerol on the film properties (water solubility, water vapor permeability and mechanical properties). The study also points to the ability of gluten-based coatings and films to extend the shelf-life of refrigerated strawberries. The influences of different types of coatings and films on the quality attributes of strawberries, such as weight loss, firmness retention, surface color development and sensory evaluation were also studied.

\section{MATERIALS AND METHODS}

Wheat gluten was obtained from Tate and Layle, Companies, France, the other ingredients used to prepare gluten films were distilled water, sodium sulfate, ethanol (96\%), ammonium hydroxide, glycerol (98\%), fatty acids, (stearic and palmitic acids). Beeswax was used as an additional additive for coatings.

Silicagel was used for determination of water vapor. Perforated polypropylene film, Organic strawberries fresh fruit (Fragaria ananassa) was obtained from the Faculty of Agriculture Farm - Cairo University.

\subsection{Preparation of wheat gluten film}

Films based on wheat gluten $(100 \mathrm{ml})$ were prepared according to Gontard et al., (1992) with some modification by Irissin-Mangata et al., (2001). Sodium sulfate $(0.3 \mathrm{~g} / 100 \mathrm{~g}$ dry gluten matter), was dissolved in $50 \mathrm{ml}$ of distilled water then added to $7.5 \mathrm{~g}$ of wheat gluten in order to cut the disulfide bonds of the gluten proteins. The components were mixed until complete homogeneous (no insoluble particles present). Ethanol $(45 \mathrm{ml})$ was added to the previous solution. Glycerol was also added at concentrations of 20, 25, 30, 35, 40, 45, 50, 55, 60 , or $70 \%(\mathrm{w} / \mathrm{w})$ of gluten, then $6 \mathrm{~N}$ ammonium hydroxide $\left(\mathrm{NH}_{4} \mathrm{OH}\right)$ was used to adjust the of solutions to $\mathrm{pH} 10$. All components were mixed on a hot plate equipped with a magnetic stirrer until the temperature of the mix reached to $70^{\circ} \mathrm{C}$ (about $10 \mathrm{~min}$ ) to improve the dispersion of gluten protein. The film-forming solution was poured and spread evenly over a Teflon Plate and dried at room temperature for $24 \mathrm{~h}$ as recommended by Tanada-Plamu et al. (2000).

\subsection{Film thicknesses}

Film thickness was measured using a micrometer (Model 49 - 50 - 02, Messmer Instrument, Germany). The thickness of the individual film samples was determined as an average of five measurements as recommended by Tanada-Palmu, and Grosso (2002).

\subsection{Opacity}

Film opacity determined as described by Gontard et al.(1992). The film sample was cut into a rectangle $(7-25 \mathrm{~mm})$ shaped strips and placed on the internal side of a spectrophotometer cell. The absorbance of spectrum (400-800 nm) was recorded for each sample using an Ultraspec 2100 pro UV / visible spectrophotometer, USA. Film opacity was defined as the area under the recorded curve determined by an integration procedure. The opacity was expressed as Absorbance Units in nanometers (AU. nm). 


\subsection{Weight loss in water}

The weight loss of film in water was determined according to the method of IrissinMangata et al.(2001). The film dispersion in water was defined by the content of dry matter that was lost after $24 \mathrm{~h}$ of immersion. Two discs of each film ( $2 \mathrm{~cm}$ diameter) were cut and weighed. One was dried at $104^{\circ} \mathrm{C} / 24 \mathrm{~h}$ to determine the percentage of initial dry matter. The other disc was immersed in $50 \mathrm{ml}$ of distilled water containing of sodium azide $(0.02 \% \mathrm{w} / \mathrm{v})$ to prevent growth of microorganisms. After $24 \mathrm{~h}$ immersion at $25^{\circ} \mathrm{C}$ with occasional stirring, the pieces of film were removed and dried to constant weight at $104^{0} \mathrm{C}$ for $24 \mathrm{~h}$ to determine the weight of dry matter that was dispersed in water. The final result of the film dispersion in water calculation was the average value of 3 measurements.

\subsection{Water vapor permeability}

Water vapor permeability (WVP) of the film was determined gravimetrically at $30^{\circ} \mathrm{C}$ as described by Gontard, et al., (1992) and IrissinMangata, et al, (2001). The tested film (discs of $37 \mathrm{~mm}$ diameter) was sealed with silicone grease in cups containing silicagel $(0 \% \mathrm{RH} ; 0 \mathrm{mmHg}$ water vapor pressure) and the cups (3.7 X $4.5 \mathrm{X}$ $3.5 \mathrm{~cm}^{3}$ ) were placed in a desiccator containing distilled water to obtain RH gradient equal to $100 \%$ (32.23 mmHg water vapor pressure). The water vapor was determined from the weight gain of the silicagel recorded at various times. The cups were weighed initially and at $6,24,48 \mathrm{~h}$ intervals. Changes in weight of the cups were recorded to the nearest $(0.1 \mathrm{mg})$. The permeability $(\mathrm{P})$ of the film was determined as follows;

$$
\begin{gathered}
W V P=(w * x) / A * T *\left(P_{2}-P_{l}\right)=(g) *(m m) / \\
\left(m^{2}\right) *(24 h) *(m m H g)
\end{gathered}
$$

Where $(\mathrm{W})$ is the weight gain of permeation cell after $24 \mathrm{~h}(\mathrm{~T}) ;(x)$ is the film thickness ; $(\mathrm{A})$ is the area of exposed film; $\left(\mathrm{P}_{2}-\mathrm{P}_{1}\right)$ is the vapor pressure differential across the film $(32.23 \mathrm{mmHg})$.

\subsection{Tensile strength and percentage elongation at break}

Film tensile strength and percentage elongation at break were determined using (A Houns Fiel D machine model H5KS, Germany) as described by Tanada-Plamu, et al. (2000). Measurements were conducted at ambient temperature $\left(25^{\circ} \mathrm{C}\right)$. Initial grip separation and crosshead speed were set at $100 \mathrm{~mm}$ and 100 $\mathrm{mm} / \mathrm{min}$, respectively. Peak loads and extension at break point were recorded for tested film specimens (150 $\mathrm{mm}$ long and $20 \mathrm{~mm}$ wide). Tensile strength of the sample was calculated by dividing peak load by cross sectional area. Thickness of individual specimens, required to calculate cross-sectional area, was determined as an average of five micrometer reading taken on each specimen before testing. Dividing extension values by the initial grip separation $(100 \mathrm{~mm})$ and multiplying by 100 yielded percentage elongations at break.

\subsection{Application of the edible film to fresh strawberries \\ 2.7.1. Sample preparation}

Organic strawberries $(F$. ananassa) at the commercially ripe stage ( $75 \%$ red color), grown in a green house in the Faculty of Agriculture Farm, Cairo University were harvested and treated in the next day. An amount of 280 fruits of uniform size, free of physical damage and fungal infection, was used. Strawberries were dipped in water and dried using tissue paper. Forty fruits, distributed randomly in four trays with 10 fruits in each tray, were used in each treatment. One tray (with 10 fruits) of each treatment was removed from the refrigerator $\left(5^{\circ} \mathrm{C}\right)$ at $1,6,12$ and 16 days of storage and used for the analyses. Six treatments were conducted. Preparation of strawberries was performed according to the method of TanadaPlamu, and Grosso, (2002).

\subsubsection{Wheat gluten - based coatings and films}

The edible wheat gluten film was applied to coat fresh strawberries to evaluate the influence of film on weight and firmness losses of the product. Four treatments were carried out to cover fresh strawberries with the gluten film as coatings and other two treatments were used as packed in films. In treatment (I) fresh strawberries were dipped into the film-forming solution $(7.5 \mathrm{~g}$ gluten +1.87 $\mathrm{g}$ glycerol $+45 \mathrm{~mL}$ ethanol $/ 100 \mathrm{~mL}$ solution, and $\mathrm{pH} 10)$ at room temperature $\left(25^{\circ} \mathrm{C}\right.$ for 1 minute (min). In treatment (II) strawberries were dipped into the same film-forming solution as treatment (I) for $1 \mathrm{~min}$ and allowed to dry for $1 \mathrm{~h}$; then they were dipped again into the same solution for $1 \mathrm{~min}$ in order to form a bilayer gluten film over the strawberries as indicated by Tanada-Plamu, and Grosso (2002). In treatment (III) the composite coating formulation was prepared by the addition of $0.45 \mathrm{~g}$ of beeswax, $0.27 \mathrm{~g}$ of stearic acid and $0.27 \mathrm{~g}$ of palmitic acid into the gluten coating formulation. This lipid containing solution was heated to $70^{\circ} \mathrm{C}$ to melt time, the lipids under vigorous magnetic stirring. In treatment (IV) (control), strawberries were dipped into distilled water for $1 \mathrm{~min}$. In treatment (V) the wheat gluten films were designed as (pouch film), pouches were prepared by first folding the gluten film in the middle and hot-sealing two sides of the film, then putting the strawberry inside the pouch and hot-sealing the third side of the film. In treatment (VI) strawberries were packed in perforated poly 
propylene. After that, all trays with strawberries were transferred into the refrigerator at $5^{\circ} \mathrm{C}$ and 60-80\% RH for 16 days to follow the shelf -life effect.

\subsubsection{Strawberry visible decay}

One tray (with 10 fruits) of each treatment was inspected after 6,12 and 16 days of storage and the fruits were considered infected when a visible lesion was observed as recommended by Tanada-Palmu, and Grosso, (2005). The visible microbial attack on the fruit was characterized as brown spots and a softening of the injured zone. The results were expressed as the percentage of infected fruits.

\subsubsection{Weight loss}

Three fruits from the tray of each treatment were weighed at the beginning of the experiment and after 1, 6, 12 and 16 days of storage as described by Tanada-Palmu, and Grosso, (2005). The trays of day 16 were chosen to follow the weight loss, since these trays would only be analyzed on the last day of the experiment. At every day of analysis, for the fruits in the gluten pouch or perforated polypropylene film, the film was taken out to weigh the same three fruits and then packed again with the same film and stored at refrigerator to continue the experiment. The results were expressed as percentage loss of initial weight.

\subsubsection{Firmness "shearing force"}

Shearing force of strawberry fruits was measured using (AMETEK /MANSFIELD \& GREEN DIV. LARGO. FLORIDA 33543, Model No. ML 3339-8). Determinations were performed on three fruits from the tray of each treatment after $1,6,12$ and 16 days of storage were the dimensions of $(2 \times 1 \mathrm{~cm})$. Firmness retention was calculated as $\left(F_{\mathrm{t}} / F_{0}\right) \times 100$, with $F_{\mathrm{t}}$ as the shear force at time $t$ and $F_{0}$ as the shear force at the beginning of the experiment as described by Tanada-Palmu, and Grosso, (2005) .The results were expressed as percentage of firmness retention.

\subsubsection{Surface color development}

Colorimetric measurements of the fruit surface were carried out with a Hunter lab Colorimeter Model D25 optical sensor (Hunter Associates Laboratory, Inc Reston, Virginia, USA) as described by Tanada-Palmu, and Grosso, (2005). The chromaticity parameters $a$ and $b$ were registered on strawberries (three fruits from the tray of each treatment) after 1, 6, 12 and 16 days of storage. There were two determinations for each strawberry, in each side of the fruit, so the results were expressed as the mean of six determinations for each treatment.

\subsubsection{Sensory evaluation of the strawberries}

The qualities of different samples of strawberries either coated or packed in films as well as the control sample were evaluated. The strawberries were evaluated after 1,6 , and 12 days of cold storage by ten panelists from the staff of Food Science and Technology Department, Faculty of Agriculture, Cairo University. The attributes analyzed were color, brightness flavor, texture and over all acceptability according to Tanada-Palmu, and Grosso (2005).

\subsection{Statistical analysis}

Results were statistically analyzed by the least significant differences (L.S.D) at the level of probability procedure according to Snedecor and Cochran (1980).

\section{RESULTS AND DISCUSSION}

\subsection{Characteristics of prepared films}

Plasticizers are generally added to films to reduce brittleness, impart flexibility, and increase strength, tear resistance and impact resistance (Banker 1966) and (Tanada-Plamu, et al., 2000). Results in Table (1) show the characteristics of (WG) films plasticized with glycerol. At 20\% added glycerol the film was brittle and fragile, however using $25 \%$ added glycerol, the film was flexible and transparent, this characteristics was with the different added concentration of glycerol up to $50 \%$; in contrast, the film become soft up to $60 \%$; added glycerol. At $70 \%$ added glycerol the film was too soft.

The mechanism by which plasticizers achieved such changes involves plasticizer polymer interaction and reduction of cumulative intermolecular forces along polymer chains leading to "softening" of the film structure (Gennadios et al., 1993).

Table (1):Characteristics of wheat gluten (WG) films plasticized with glycerol (GLY) at ambient temperature and relative humidity.

\begin{tabular}{|c|l|}
\hline \multicolumn{1}{|c|}{ Film } & \multicolumn{1}{|c|}{ Characteristics } \\
\hline $\begin{array}{c}\text { Wheat gluten with: } \\
20 \% \text { GLY }\end{array}$ & brittle and fragile \\
\hline $25 \%$ GLY & Flexible and transparent \\
\hline $30 \%$ GLY & Flexible and transparent \\
\hline $35 \%$ GLY & Flexible and transparent \\
\hline $40 \%$ GLY & Flexible and transparent \\
\hline $45 \%$ GLY & Flexible and transparent \\
\hline $50 \%$ GLY & Flexible and transparent \\
\hline $55 \%$ GLY & Flexible, transparent and soft \\
\hline $60 \%$ GLY & Flexible, transparent and soft \\
\hline $70 \%$ GLY & Too soft \\
\hline
\end{tabular}

\subsection{2. Water vapor permeability}

Water vapor permeabilities (WVP) of wheat gluten films with different levels of glycerol at $30^{\circ} \mathrm{C}$ and $0 / 100 \%$ relative humidity are shown in 
Table (2). Significant differences among all the tested film samples are clearly shown. The lowest WVP was for the film containing 25\% glycerol. As the concentration of glycerol increased the WVP increased that means directly proportional. As shown by Gontard et al.(1993); Park et al., (1994), and Tanada-Palmu, et al.(2000) found that water vapor permeability (WVP) increased with increasing glycerol concentration.

By the modifications of the protein structure, which might become less dense, and by the hydrophilicity of glycerol, which favors adsorption and desorption of water molecules in addition the WVP should be as low as possible, since an edible film or coating should retard moisture transfer between the food and the environment, or between two components of a heterogeneous food product (Gontard et al., 1992).

Table (2). Water vapor permeability (WVP) of wheat gluten (WG) films with different levels of glycerol at $30^{\circ} \mathrm{C}$ and $\mathbf{0} / 100 \%$ relative humidity.

\begin{tabular}{|c|c|c|c|}
\hline Film & $\begin{array}{c}\text { Tensile } \\
\text { strength } \\
(\mathbf{M P a})\end{array}$ & $\begin{array}{c}\text { Break } \\
\mathbf{N}\end{array}$ & $\begin{array}{c}\text { Elongati } \\
\text { on \% }\end{array}$ \\
\hline Wheat gluten with: & $7.88^{\mathrm{a}}$ & $10.63^{\mathrm{a}}$ & $133.13^{\mathrm{e}}$ \\
\hline 25\% GLY & $7.42^{\mathrm{a}}$ & $10.01^{\mathrm{a}}$ & $167.47^{\mathrm{d}}$ \\
\hline $30 \%$ GLY & $7.09^{\mathrm{ab}}$ & $8.31^{\mathrm{b}}$ & $229.43^{\mathrm{c}}$ \\
\hline $35 \%$ GLY & $6.03^{\mathrm{b}}$ & $7.23^{\mathrm{b}}$ & $249.37^{\mathrm{c}}$ \\
\hline $40 \%$ GLY & $3.54^{\mathrm{c}}$ & $4.25^{\mathrm{c}}$ & $253.40^{\mathrm{c}}$ \\
\hline $45 \%$ GLY & $2.93^{\mathrm{cd}}$ & $4.18^{\mathrm{c}}$ & $289.40^{\mathrm{b}}$ \\
\hline $50 \%$ GLY & $2.45^{\mathrm{d}}$ & $4.74^{\mathrm{c}}$ & $293.37^{\mathrm{b}}$ \\
\hline $55 \%$ GLY & $2.31^{\mathrm{cd}}$ & $5.34^{\mathrm{c}}$ & $329.33^{\mathrm{a}}$ \\
\hline $60 \%$ GLY & \multicolumn{2}{|l}{}
\end{tabular}

\subsection{Mechanical properties}

An edible film should be resistant in order to withstand the manipulation during its application and to maintain its integrity and also its barrier properties, (Tanada-Plamu, and Grosso, 2002). Tensile strength was decreased and the percentage elongation at break was increased with increasing glycerol concentration as shown in Table (3). Apparently, glycerol is a small hydrophilic molecule which could be inserted between protein chains. With glycerol in the protein network the distance between protein chains was increased and direct interactions were reduced. An alkaline environment and heating are necessary to denature the gluten protein, thus disrupting protein structure, breaking existing disulfide intramolecular bonds and exposing sulphydryl and hydrophobic groups, making them available for bonding. The cleavage of disulfide bonds results in polypeptide chains with lower molecular weights, destroying elasticity and cohesiveness of gluten. Upon casting and drying, sulphydryl groups reform disulfide bonds by air oxidation, which leads the film structure (Gennadios et al., 1993).

Table (3): Mechanical properties of wheat gluten (WG) films with different levels of glycerol.

\begin{tabular}{|c|c|}
\hline Film & $\begin{array}{c}\text { Water vapor } \\
\text { permeability } \\
\left(\mathrm{gmm} / \mathbf{m}^{2} \mathrm{dkpa}\right)\end{array}$ \\
\hline $\begin{array}{l}\text { Wheat gluten with: } \\
25 \% \text { GLY }\end{array}$ & $2.5^{\mathrm{f}}$ \\
\hline $30 \%$ GLY & $2.7^{\mathrm{ef}}$ \\
\hline $35 \%$ GLY & $2.8^{\mathrm{def}}$ \\
\hline $40 \%$ GLY & $3.2^{\mathrm{de}}$ \\
\hline $45 \% \mathrm{GLY}$ & $3.4^{\mathrm{d}}$ \\
\hline $50 \%$ GLY & $4.5^{c}$ \\
\hline $55 \% \mathrm{GLY}$ & $6.1^{b}$ \\
\hline $60 \%$ GLY & $7.2^{\mathrm{a}}$ \\
\hline
\end{tabular}

Table (4): Solubility in water and opacity of wheat gluten (WG) films with different levels of glycerol.

\begin{tabular}{|c|c|}
\hline Film & Solubility in water \% \\
\hline $\begin{array}{c}\text { Wheat gluten with: } \\
25 \% \text { GLY }\end{array}$ & $12^{\mathrm{c}}$ \\
\hline $30 \%$ GLY & $14.8^{\mathrm{c}}$ \\
\hline $35 \%$ GLY & $16.7^{\mathrm{bc}}$ \\
\hline $40 \%$ GLY & $38.5^{\mathrm{ab}}$ \\
\hline $45 \%$ GLY & $42.6^{\mathrm{a}}$ \\
\hline $50 \%$ GLY & $33.2^{\mathrm{ab}}$ \\
\hline $55 \%$ GLY & $39.1^{\mathrm{a}}$ \\
\hline 60\% GLY & $40.9^{\mathrm{a}}$ \\
\hline The LSD at 5\% & $\mathbf{2 2 . 1 5}$ \\
\hline
\end{tabular}

\subsection{Solubility in water}

Solubility (\%) of wheat gluten film with different levels of glycerol in water is shown in Table (4). Results show that, as the percentage of glycerol (plasticizer) increased with the solubility of the prepared film increases. These results are in accordance with those obtained by Tanada-Plamu, and Grosso.(2002) who found that the solubility (\%) of WGF with $25 \%$ glycerol was $11.1 \%$, meanwhile it was found to be $17.4 \%$ solubility for the WGF prepared with $35 \%$ glycerol. The solubility matter in water is likely consisted of the plasticizer and some protein chains of low molecular weight (Cuq et al., 1997).

Water resistance is an important property of edible films for applications in food protection, where water activity is high, or when the film must be in contact with water during processing of the coated food to avoid exudation of fresh or frozen products (Gontard et al., 1993).

3.5. Wheat gluten coatings and film as well as synthetic film (perforated polypropylene) for strawberries packaging

Edible wheat gluten coatings (one layer, bilayer and composite) and other films were applied for strawberry fruits in order to rmoisture and firmness losses and also to extend the shelf 
Table (5): Mean of the attributes in the sensory evaluation for the shelf life of four samples of strawberry stored at $5^{\circ} \mathrm{C}$ during 16 days.

\begin{tabular}{|c|c|c|c|c|c|}
\hline \multirow[t]{2}{*}{ Parameter } & \multirow[t]{2}{*}{ Treatment } & \multicolumn{4}{|c|}{ Storage time at $7-10^{0} \mathrm{C}$} \\
\hline & & 1 day & 6 days & 12 days & $\begin{array}{l}\text { LSD at } \\
5 \%\end{array}$ \\
\hline \multirow[t]{8}{*}{ Color } & Control & $7.8^{\mathrm{bA}}$ & $6^{\mathrm{cA}}$ & $3.5^{\mathrm{cB}}$ & 2.14 \\
\hline & Coatings: & & & & \\
\hline & - Gluten (one layer) & $7.3^{\mathrm{bA}}$ & $8.1^{\mathrm{abA}}$ & $5.4^{\mathrm{abB}}$ & 1.68 \\
\hline & - Composite & $8.1^{\mathrm{abA}}$ & $8.4^{\mathrm{abA}}$ & $6.9^{\mathrm{aA}}$ & 0 \\
\hline & -Bilayer & $8.7^{\mathrm{aA}}$ & $8.8^{\mathrm{aA}}$ & $6.9^{\mathrm{aA}}$ & 0 \\
\hline & Films: & & & & \\
\hline & - Gluten pouch film & $7.9^{\mathrm{bA}}$ & $6.8^{\mathrm{bcA}}$ & $4.9^{\mathrm{bcA}}$ & 0 \\
\hline & $\begin{array}{l}\text { - Perforated } \\
\text { polypropylene }\end{array}$ & $6.4^{\mathrm{cA}}$ & $6.1^{\mathrm{cA}}$ & $3.9^{\mathrm{bcB}}$ & 1.25 \\
\hline \multicolumn{2}{|c|}{ LSD at $5 \%$} & 0.88 & 1.85 & 1.55 & \\
\hline \multirow[t]{9}{*}{ Brightness } & Control & $5.3^{\mathrm{bA}}$ & $4.9^{\mathrm{bA}}$ & $2.9^{\mathrm{cB}}$ & 2.14 \\
\hline & Coatings: & & & & \\
\hline & - Gluten (one layer) & $7.8^{\mathrm{aA}}$ & $7.5^{\mathrm{aA}}$ & $4.9^{\mathrm{abB}}$ & 1.76 \\
\hline & - Composite & $8.3^{\mathrm{aA}}$ & $8.1^{\mathrm{aA}}$ & $6.5^{\mathrm{aA}}$ & 0 \\
\hline & -Bilayer & $8.4^{\mathrm{aA}}$ & $8.8^{\mathrm{aA}}$ & $6.6^{\mathrm{aA}}$ & 0 \\
\hline & Films: & & & & \\
\hline & - Gluten pouch film & $6.1^{\mathrm{bA}}$ & $5.9^{\mathrm{bcA}}$ & $4.1^{\mathrm{bcA}}$ & 0 \\
\hline & $\begin{array}{l}\text { - Perforated } \\
\text { polypropylene }\end{array}$ & $5.4^{\mathrm{bA}}$ & $4.6^{\mathrm{cA}}$ & $2.9^{\mathrm{bcB}}$ & 1.36 \\
\hline & $5 \%$ & 1.15 & 2.03 & 1.83 & \\
\hline \multirow[t]{9}{*}{ Flavor } & Control & $9.2^{\mathrm{aA}}$ & $9.4^{\mathrm{aA}}$ & $7.1^{\mathrm{aB}}$ & 0.83 \\
\hline & Coatings: & & & & \\
\hline & - Gluten (one layer) & $6.7^{\mathrm{cA}}$ & $5.4^{\mathrm{cA}}$ & $4.7^{\mathrm{cB}}$ & 1.17 \\
\hline & - Composite & $7^{\mathrm{bcA}}$ & $6.1^{\mathrm{bcA}}$ & $5^{\mathrm{bcA}}$ & 0 \\
\hline & -Bilayer & $8.3^{\mathrm{abA}}$ & $8.2^{\mathrm{abA}}$ & $6.2^{\mathrm{abA}}$ & 0 \\
\hline & Films: & & & & \\
\hline & - Gluten pouch film & $8.5^{\mathrm{aA}}$ & $7.4^{\mathrm{bA}}$ & $5.8^{\mathrm{bB}}$ & 1.67 \\
\hline & $\begin{array}{l}\text { - Perforated } \\
\text { polypropylene }\end{array}$ & $8.1^{\mathrm{abA}}$ & $7.1^{\mathrm{bcA}}$ & $5.2^{\mathrm{bcB}}$ & 1.35 \\
\hline & $5 \%$ & 1.32 & 1.39 & 1.27 & \\
\hline \multirow[t]{9}{*}{ Texture } & Control & $9.1^{\mathrm{aA}}$ & $6.9^{\mathrm{cbB}}$ & $3.2^{\mathrm{cC}}$ & 2.28 \\
\hline & Coatings: & & & & \\
\hline & - Gluten (one layer) & $7^{\mathrm{bA}}$ & $7.6^{\mathrm{abcAB}}$ & $4.4^{\mathrm{bcB}}$ & 1.76 \\
\hline & - Composite & $7^{\mathrm{bA}}$ & $8.4^{\mathrm{abcA}}$ & $6.4^{\mathrm{abA}}$ & 0 \\
\hline & -Bilayer & $7^{\mathrm{bA}}$ & $8.7^{\mathrm{aA}}$ & $7.1^{\mathrm{aA}}$ & 0 \\
\hline & Films: & & & & \\
\hline & - Gluten pouch film & $8.3^{\mathrm{abA}}$ & $7^{\mathrm{cbA}}$ & $4.1^{\mathrm{cB}}$ & 1.63 \\
\hline & $\begin{array}{l}\text { - Perforated } \\
\text { polypropylene }\end{array}$ & $7.6^{\mathrm{bA}}$ & $6.3^{\mathrm{cA}}$ & $3.4^{\mathrm{cB}}$ & 1.52 \\
\hline & $5 \%$ & 1.01 & 1.67 & 2.02 & \\
\hline \multirow[t]{9}{*}{$\begin{array}{c}\text { Overall } \\
\text { acceptability }\end{array}$} & Control & $6.3^{\mathrm{bA}}$ & $5.2^{\mathrm{cA}}$ & $4.1^{\mathrm{eC}}$ & 1.66 \\
\hline & Coatings: & & & & \\
\hline & - Gluten (one layer) & $7^{\mathrm{abA}}$ & $7.4^{\mathrm{abAB}}$ & $5.9^{\mathrm{bcB}}$ & 1.37 \\
\hline & - Composite & $7.1^{\mathrm{abA}}$ & $8.2^{\mathrm{abA}}$ & $7.5^{\mathrm{aA}}$ & 0 \\
\hline & -Bilayer & $8^{\mathrm{aA}}$ & $8.6^{\mathrm{aA}}$ & $6.8^{\mathrm{abA}}$ & 0 \\
\hline & Films: & & & & \\
\hline & - Gluten pouch film & $6.9^{\mathrm{abA}}$ & $6.7^{\mathrm{bcA}}$ & $5.4^{\mathrm{cdA}}$ & 0 \\
\hline & $\begin{array}{l}\text { - Perforated } \\
\text { polypropylene }\end{array}$ & $6.1^{\mathrm{bA}}$ & $5.8 \mathrm{cA}$ & $4.5^{\mathrm{deA}}$ & 0 \\
\hline & $5 \%$ & 1.13 & 1.59 & 1.83 & \\
\hline
\end{tabular}


-life of the fruits that are indicated by visible decay during cold storage (16 days) as recommended by Tanada-Palmu and Grosso (2005) and Garcia et al. (1998a).

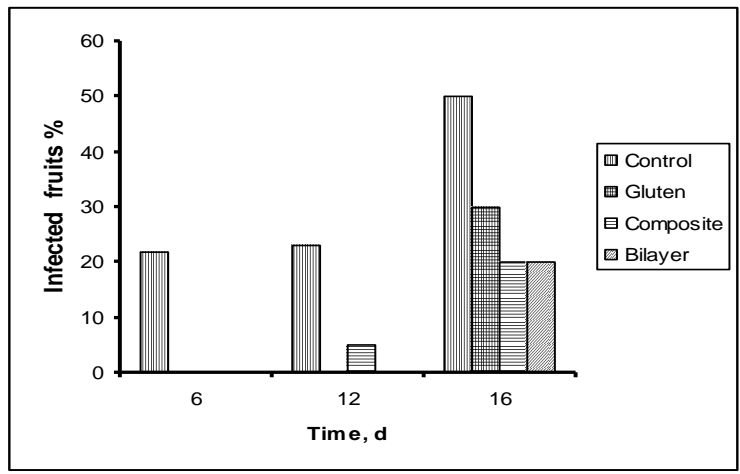

(a)

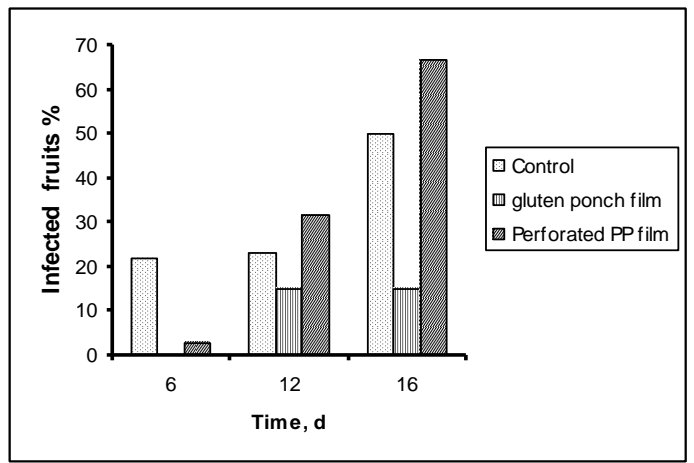

(b)

Fig. (1). Visible decay of strawberries either coated (a) or packed in films (b). Results expressed as percentage of infected fruit during storage time.

\subsubsection{Strawberry visible decay}

Strawberry is a highly perishable fruit and the shelf life usually ends due to fungal infection (Maas, 1981). In this work, the maximum storage life was defined as the time elapsed between the application of coatings as well as films and the visualization of fungal injury. Percentage (\%) of infected fruits was $22 \%$ for the control fruit during the storage time after 6 days. Shelf-life of the Gluten and bilayer coated fruit and the fruit maintained in the gluten pouch film extended up to 12 days without decay. These results are reported by Tanada-Palmu, and Grosso (2005) and Garcia et al. (1998a), who found that the coatings and pouch film markedly reduced the number of infected fruits and extended the storage life. However, perforated polypropylene did not reduce the number of infected fruit at the end of the storage time as compared to the control treatment (Fig. 1b). The gluten pouch film and the coatings of one layer gluten, bilayer and composite were significantly reduced the number of infected fruit in comparison with the control fruits at the end of the experiment (Fig. 1a). The gluten film was more effective for reducing the number of infected strawberries than the coated fruits. The films and coatings can reduce decay by delaying senescence, which makes the commodity more vulnerable to pathogenic infection as a result of the loss of the cellular or tissue integrity (Tanada-Palmu, and Grosso, 2005).

\subsubsection{Weight loss}

Weight loss of the fruits increased with the storage time for the control and those coated or packed with films (Fig. 2 a \&b). Results showed a significance increases in weight loss for all treatments. However, the weight loss of the control sample was significantly higher than the other treatments. On the contrary, the strawberry fruits coated with the bilayer coating were superior than the other treated samples that had the lowest weight loss (Fig. 2a). A similar effect was also observed by Garcia et al. (1998a, 1998b) for strawberries coated with starch-based coatings and those by Tanada-Plamu, and Grosso (2002). The same bilayer coating significantly reduced the weight loss of strawberries comparing to a single layer of gluten coating.

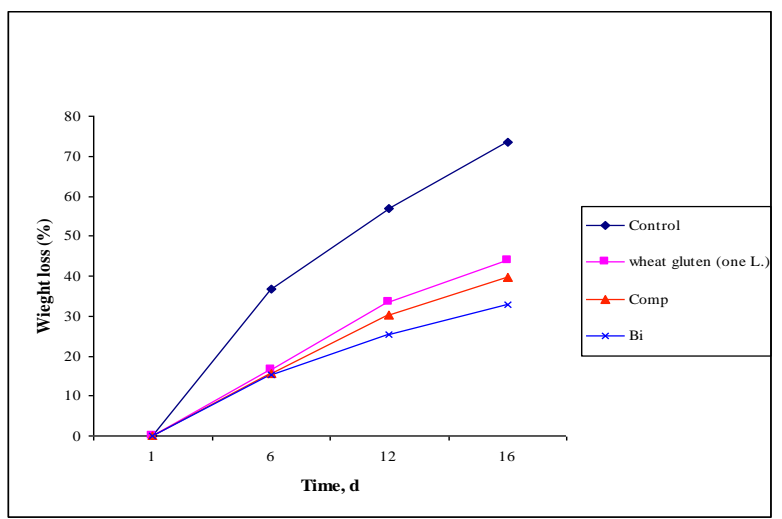

(a)

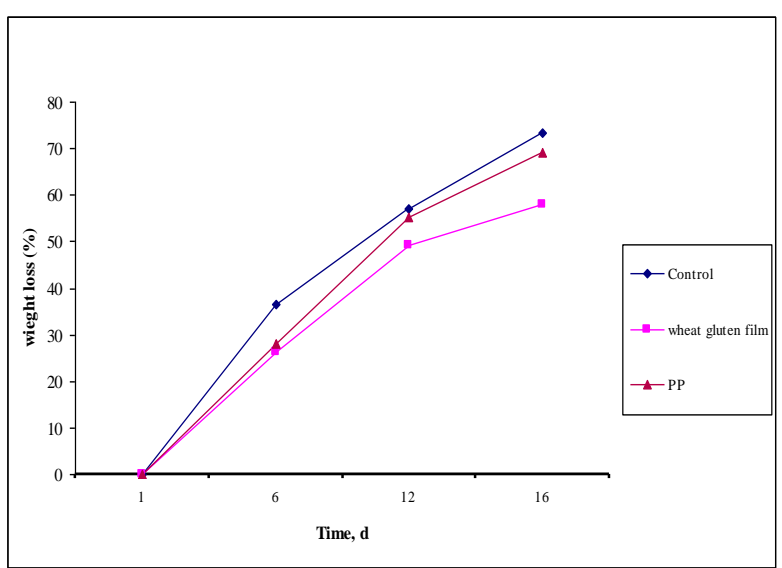

(b)

Fig. (2):Effect of gluten-based coatings (a) and films (b) on weight loss of strawberries during storage. 


\subsubsection{Firmness}

Firmness retention was calculated as $\left(F_{\mathrm{t}} / F_{0}\right)$ $\times 100$, at different storage times in days as shown in Fig. 3 (a) and (b). Results in Fig. 3 (a) and (b) show that, all the coating samples, gluten pouch film as well as perforated polypropylene film was statistically significant compared to the control. Firmness of the control sample was gradually decreased during the storage period. Results in Fig. 3 (a) and (b) were statistically analyzed, so, at the end of the experiment (16 days) firmness retention of the wheat gluten coating (one layer) on strawberries (Fig. 3a) was statistically significant which was higher than the wheat gluten pouch film (Fig. 3b). The delay in senescence may be due to the development of an adequate internal atmosphere in coated fruit as observed by Carrilo-Lopez et al. (2000). The bilayer and composite coatings showed a good result with respect to the retention of fruit firmness probably because this coating might be

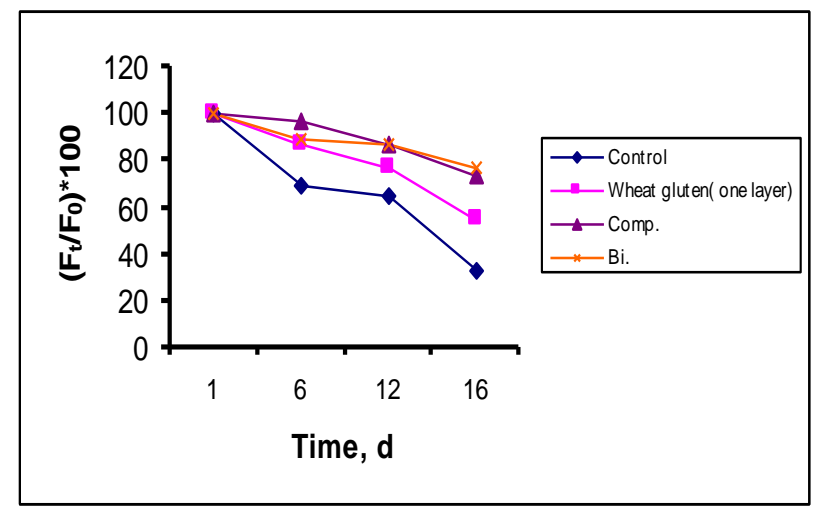

slowed down metabolism and prolonged the storage life, an effect was previously observed by El Gaouth et al. (1991).

(a)

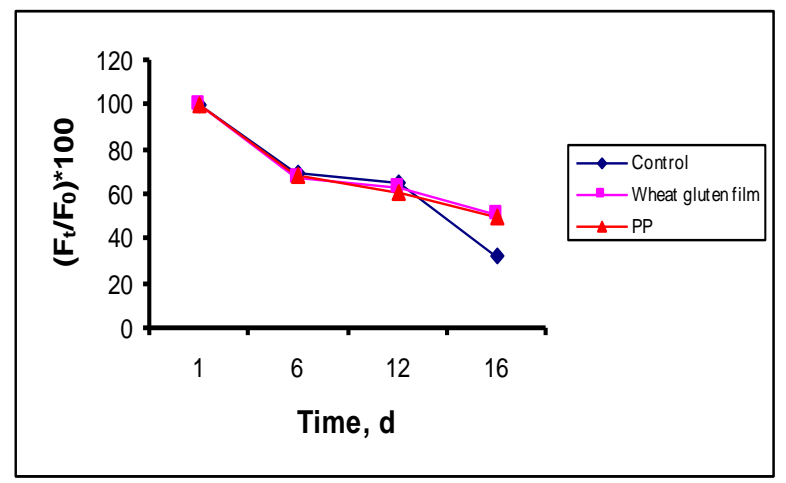

(b)

Fig. (3): Effect of coatings (a) and films (b) on firmness retention of strawberries during storage

\subsubsection{Surface color development}

Color changes during storage of different samples were observed by an increase in $\mathrm{a} / b$ ratio with an increase in redness $(a)$ and a decrease in yellowness (b). Results in Fig.( 4 ) a and b, showed that $\mathrm{a} / b$ ratios were increased with the storage time increases in all treatments. Control sample showed the highest $\mathrm{a} / \mathrm{b}$ values during storage that were statistically significant in comparison with all of the other treatments. Thus these coatings and films were effective to promote a small delay of surface color development compared with the control treatment, as were previously observed by Tanada-Palmu, and Grosso (2005).

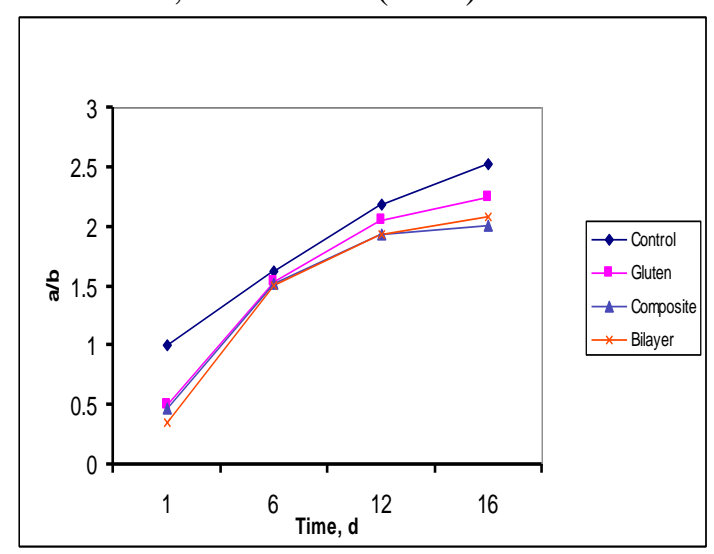

(a)

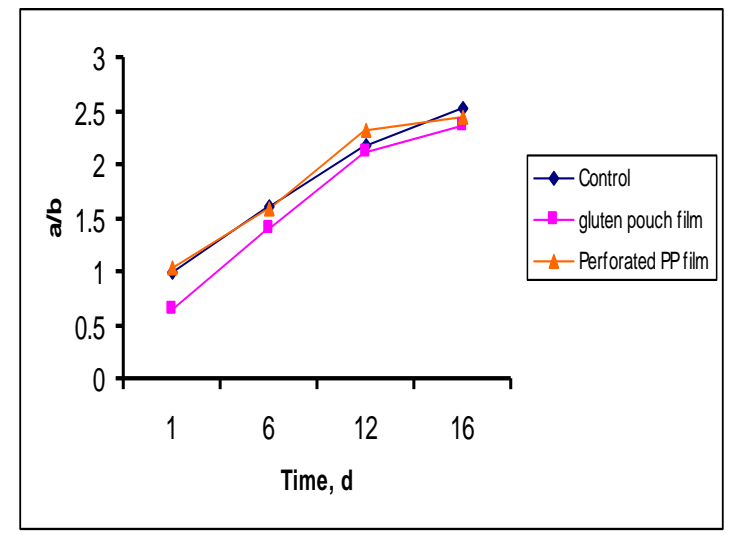

(b)

Fig. (4): Surface color changes of coated (a) and packed (b) strawberriesduring storage.

\subsubsection{Sensory evaluation of the strawberries}

Results of sensory evaluation of different strawberrys samples showed significant differences $(P<0.05)$ (Table 5). The bilayer coated fruits as well as the composite coated fruits were superior to the other examined samples for color, brightness, and overall acceptability during all storage periods. Meanwhile, the flavor of bilayer coated strawberry fruits was significantly different $\left(\begin{array}{ll}P & <0.05) \\ \end{array}\right)$ compared with the corresponded fruits coated with composite coating. They show such improve in their texture, as the storage time increased, indicated that, the ability of coating materials to absorb water denote the sence of good texture as mentioned by Tanada-Palmu, and Grosso (2005).

Control strawberry samples showed graduall decrease for all the tested parameters throughout the storage times. Strawberry fruits packed into perforated polypropylene showed significant difference $(P<0.05)$ for their color, brightness and 
texture during storage time up to 12 days that affected by the surrounded environmental conditions.

\section{Conclusions}

Wheat gluten can be used as a source of protein-based biodegradable films and coatings. Different concentrations of glycerol (as plasticizer) influenced the characteristics of wheat gluten films like water vapor and mechanical properties (tensile strength and percent elongation at break). Results showed that the addition of plasticizer generally increased water vapor and solute permeability of the film, and decreased the tensile strength. Gluten based films showed promising as protective coatings materials for perishable foods such as strawberries. Wheat gluten coatings and films extended the shelf life of strawberries and retarded the senescence process compared with strawberries used as a control treatment. The addition of lipids to the gluten coatings composite showed a beneficial effect on firmness retention and reduced weight loss of strawberries. The fruit with the gluten pouch film also had higher firmness retention compared to the control fruit, and reduced the number of infected fruit in comparison with the control fruit. The sensory evaluation of the strawberries showed that fruits with coatings maintained their quality during storage time and the consumers approved the taste and flavor of the different gluten-coated fruits.

\section{REFERENCES}

Ahvenainen R.T., Hurme E.U., Hagg M., Skytta E.H. and Laurila E.K. (1998). Shelf-life of prepeeled potato cultivated, stored, and processed by various methods, J. Food Prot. 61 (5) 591-600.

Banker G. S. (1966). Film coating theory and practice. Journal of Pharmaceutical Science. 55: 81-89.

Carrilo-Lopez A., Ramirez-Bustamante F., Valdez-Torrez J.B. and Rojas Villegas R. (2000). Ripening and quality changes in mango fruit as affected by coating with an edible film. J. Food Qual. 23, 479-486.

Cuq B., Gontard N., Cuq L. and Guilbert S. (1997). Selected Functional Properties of Fish Myofibrillar Protein-Based Films As Affected by Hydrophilic Plasticizers. J. Agric. Food Chem., 45 (3), 622 -626.

Debeaufort F., Quezada-Gallo J.-A. and Voilley A. (1998). Edible films and coatings: tomorrows packaging: a review. Crit. Rev. Food Sci.38, 299-313.

Diab T., Biliaderis C. G., Gerasopoulos D. and Sfakiotakis

E.(2001).Physicochemical properties and application of pullulan edible films and coatings in fruit preservation. Journal of the Science of Food and Agriculture. 81:988-1000.

El Gaouth A., Arul J., Ponnampalam R. and Boulet M. (1991). Chitosan coating effect on storability and quality of fresh strawberries. J. Food Sci. 56 (6), 16181620, 1631.

Garcia M.A., Martino M.N. and Zaritzky N.E. (1998a). Starch-Based Coatings: Effect on Refrigerated Strawberry (Fragaria ananassa) Quality. J Sci Food Agric 76, 411- 420.

Garcia M.A., Martino M.N., and Zaritzky N.E. (1998b). Plasticized starch-based coatings to improve strawberry (Fragaria ananassa) quality and stability. J. Agric. Food Chem. 46, 3758-3767.

Gennadios A., Brandenburg A.H, Weller C.L., and Testin R. F. (1993). Effect of $\mathrm{pH}$ on properties of wheat gluten and soy protein isolate films. Journal of Agriculture and Food Chemistry, 41: 1835-1839.

Gontard N., Guilbert S. and Cuq J.L. (1992). Edible wheat gluten films: influence of the main process variables on film properties using response surface methodology. J. Food Sci. 57, 190-195 also p. 199.

Gontard N., Guilbert S. and Cuq J.L. (1993). Water and glycerol as plasticizer affect mechanical and water vapor barrier properties of an edible wheat gluten film. J. Food Sci. 58 (1), 206-211.

Irissin-Mangata J., Bauduin G., Boutevin B. and Gontard N. (2001). New plasticizers for wheat gluten films. European Polymer Journal 37: 1533-1541.

Kayserilioglu B. S., Bakir U., Yilmaz L. and Akkas N. (2003). Use of xylan, an agricultural by-product, in wheat gluten based biodegradable films: mechanical, solubility and water vapor transfer rate properties. Bioresource Technology 87: 239-246.

Krochta J.M. and De Mulder-Johnston C. (1997). Edible and biodegradable polymer films: challenges and opportunities. Food Technol. 51, 61-74.

Maas J.L. (1981). Postharvest diseases of strawberry. In: Childers, N.F. (Ed.), the Strawberry-Cultivars to Marketing. Horticultural Publications, Gainesville, FL, USA, p. 329-353.

Mastromatteo M., Chillo S., Buonocore G., Massaro A., Conte A., and Del Nobile M. (2008). Effects of spelt and wheat bran on 
the performances of wheat gluten films. Journal of Food Engineering 88: 202-212.

Mujica Paz H. and Gontard N. (1998). Oxygen and carbon dioxide permeability of wheat gluten film: effect of relative humidity and temperature. Journal of Agricultural and Food Chemistry 45, 4101-4105.

Park H.J., Bunn J.M., Weller C.L., Vergano P.J. and Testin R. F. (1994). Water vapor permeability and mechanical properties of grain protein based film as affected by mixtures of polyethylene glycol and glycerin plasticizers. Transactions of ASAE 37: 12811285.

Pommet M., Redl A., Guilbert S. and Morel M. (2005). Intrinsic influence of various plasticizers on functional properties and reactivity of wheat gluten thermoplastic materials. Journal of Cereal Science 42: 8191.
Snedecor G.W. and Cochran W.G. (1980). Statistical Methods. Oxford and J.B.H.Publishing Com $7^{\text {th }}$ edition.

Tanada-palmu P., Helen H. and Hayvonen L. (2000). Preparation, properties and applications of wheat gluten edible films. Agriculture and Food Science in Finland 9: 23-35.

Tanada-palmu P. and Grosso C. (2002). Edible wheat gluten films: development, mechanical, and barrier properties and application to strawberries (Fragaria ananassa). B.CEPPA, Curitiba, 20: (2) 291 -308 .

Tanada-Palmu P. and Grosso C. (2005). Effect of edible wheat gluten-based films and coatings on refrigerated strawberry (Fragaria ananassa) quality. Postharvest Biology and Technology 36:199-208.

\title{
تعبئة وتظليف ثمار الفراولة المبردة (Fragaria ananassa) بإستخدام أغشية مصنعة من جلوتين القمح

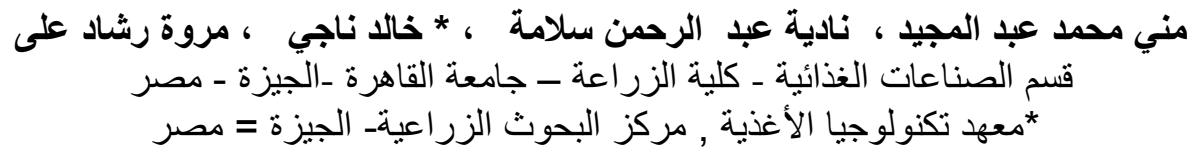

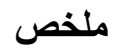

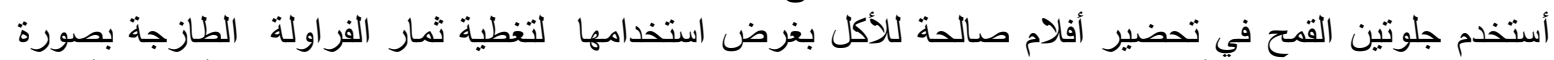

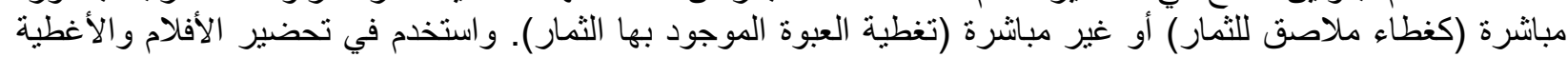

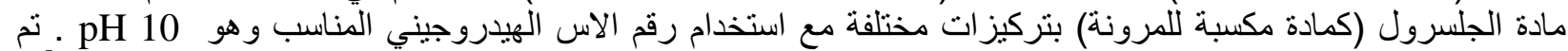

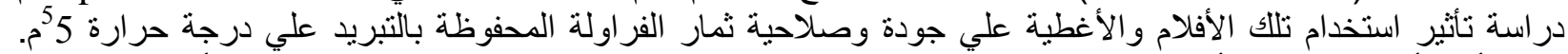

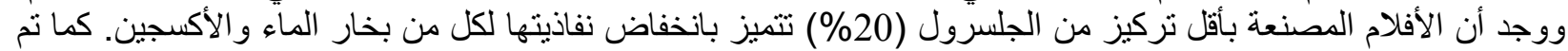

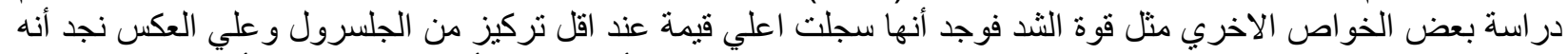

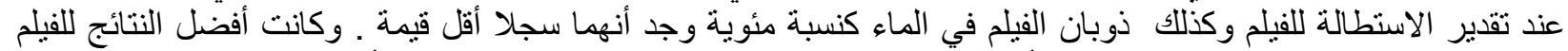

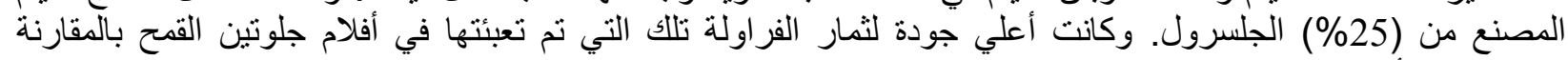

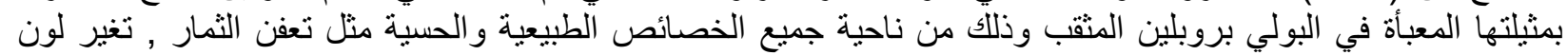

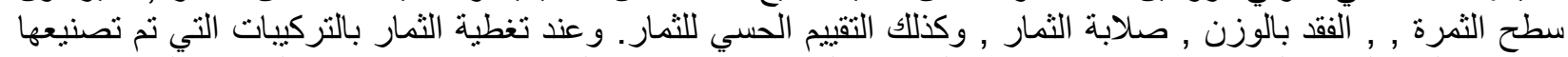

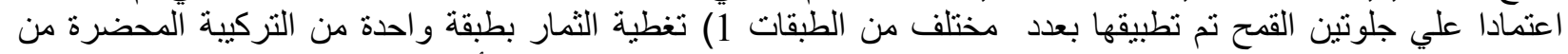

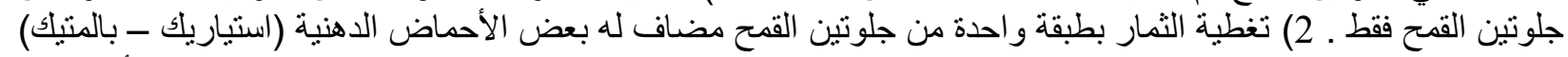

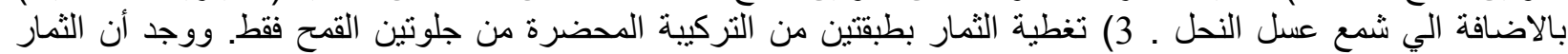

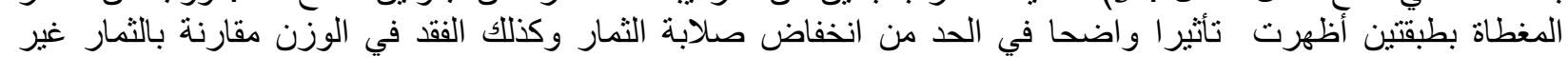

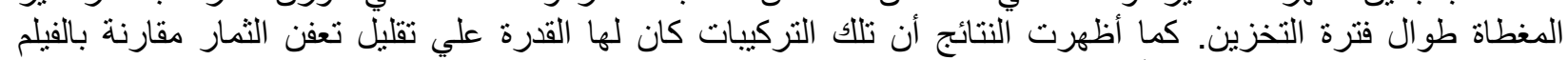

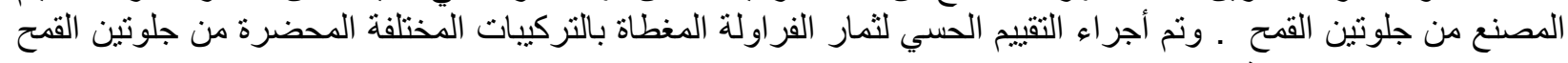

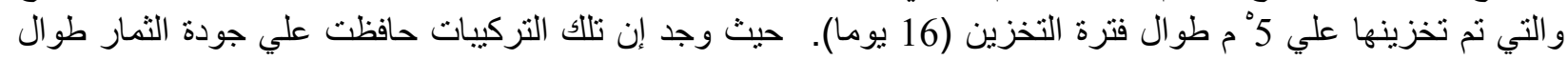

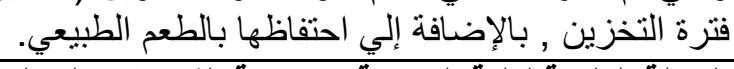

